\title{
Potential environmental drivers of a regional blue mussel mass mortality event (winter 2014, Breton Sound, France)
}

\author{
Polsenaere Pierre ${ }^{1,}{ }^{*}$, Soletchnik Patrick ${ }^{2}$, Le Moine Olivier ${ }^{2}$, Gohin Francis ${ }^{3}$, Robert Stephane ${ }^{2}$, \\ Pépin Jean-Francois ${ }^{2}$, Stanisière Jean-Yves ${ }^{4}$, Dumas Franck ${ }^{5}$, Béchemin Christian ${ }^{6}$, \\ Goulletquer Philippe ${ }^{7}$
}

${ }^{1}$ IFREMER, Laboratoire Environnement Ressources des Pertuis Charentais (LER/PC), BP7, 17137

L'Houmeau, France

${ }^{2}$ IFREMER, Laboratoire Environnement Ressources des Pertuis Charentais (LER/PC), BP133, 17390

La Tremblade, France

${ }^{3}$ IFREMER, DYNamiques de I'Environnement COtier (DYNECO/PELAGOS), BP70, 29280 Plouzané,

France

${ }^{4}$ IFREMER, Laboratoire Environnement Ressources Morbihan-Pays de la Loire (LER/MPL), BP86, 56470 La Trinité sur mer, France

${ }^{5}$ IFREMER, DYNamiques de l'Environnement COtier (DYNECO/DHYSED), BP70, 29280 Plouzané, France

${ }^{6}$ IFREMER, Laboratoire de Génétique et Pathologie des Mollusques Marins, SG2M-LGPMM, 17390 La

Tremblade, France

${ }^{7}$ IFREMER, Direction Scientifique, BP21105, 44311 Nantes, France

* Corresponding author : Pierre Polsenaere, email address : pierre.polsenaere@ifremer.fr

\begin{abstract}
:
In the context of global change, increasing mariculture production has raised particular concerns regarding its environmental impact and sustainability. Molluscs and particularly blue mussel account for a significant part of this total production. Although blue mussels are considered as pretty resilient to environmental disturbances, we report in this study an unprecedented mussel mortality event that occurred during the winter 2014 in the Breton Sound. 9000 metric tonnes of mussels were lost and mortality rates up to $100 \%$ were recorded at some farming areas. Through a coupling approach, the present work aimed to better understand the potential environmental drivers associated to those mortalities. Firstly we analysed long-term in situ and satellite data from environmental monitoring networks (available since 1998) to characterize the variability of seawater masses of the sound during the winter of 2014. Secondly we used modelling simulations to study the possible relationship between seawater hydrodynamics and observed spatio-temporal patterns of mussel mortalities. From January to April 2014 at the long-line culture site where mortalities started, seawater temperatures ranged from 8.3 to $13.3^{\circ} \mathrm{C}\left(10.2 \pm 0.8^{\circ} \mathrm{C}\right)$. Salinity and turbidity values showed successive and short drops (below 16 ; $29.3 \pm 2.3$ ) and numerous peaks (above 70 NTU; $17.4 \pm 13.4$ NTU) respectively. Winter conditions of 2014 were encountered along the entire French Atlantic coastline and linked to the sixth highest positive North Atlantic Oscillation (NAO +) index computed since 1865. These particular environmental variations characterized the winter of 2014 but also others whereas no comparable mussel mortality rates were reported. Exact causes of the 2014 mortality event are still unknown but we showed these
\end{abstract}


environmental variations could not alone be responsible. These likely affected the sensitivity of the blue mussel populations that were already weakened by early spawning. Meanwhile, these may have facilitated the apparition of a pathogenic strain of Vibrio splendidus isolated on moribund mussels at that time. Our modelling simulations suggested that this pathogenic strain could spread through hydrodynamic patterns and drove the observed mussel mortalities. If repeated over the coming years particularly under climate change, mussel mass mortality events could question about the resilience of this species.

\section{Highlights}

- A significant French production area lost $9000 \mathrm{t}$ of blue mussels in winter 2014. We studied potential environmental drivers linked to those unprecedented mortalities. This winter 2014 had the sixth highest $\mathrm{NAO}+$ index since 1865. - Such conditions characterized other winters without comparable mortalities in the area. Hydrodynamic connectivity participated to specific mortality vector diffusion.

Keywords: Mytilus edulis mortalities, Climate change, Breton sound, Long-term monitoring, Hydrodynamic modelling, Vibriosis 


\section{Introduction}

Globally, marine ecosystems are among the most valuable and heavily used natural systems (Staudinger et al. 2012). They provide many ecosystem services including shoreline protection, tourism activities, seawater filtration, nursery grounds, food from fisheries and aquaculture (MEA 2005, Ruckelshaus et al. 2013). Worldwide, aquaculture has grown rapidly and currently represents the fastest growing sector of the food industry. It increases at a rate of approximately $8 \%$ per year since the 1970's (McKindsey et al. 2011, FAO 2013). Global mariculture production is now close to $40 \%$ of total aquaculture production. $75 \%$ of mariculture results from shellfish production with molluscs (i.e., mussel, oyster, and abalone) accounting for $71 \%$ of the total production (Bouwman et al. 2013). This increased production and the associated issues have raised concerns regarding interactions between mariculture and local environments (Black 2001). Several studies have aimed to understand the role of bivalve farming in terms of ecosystem services and also environmental impact and sustainability (Davenport et al. 2003, Holmer et al. 2008). For example, enhanced localized biodeposition (Mattsson and Lindén 1983), seawater column filtration (Troost et al. 2009), and nutrient and oxygen exchange modifications (Richard et al. 2007) as a result of the presence of bivalve farms are commonly addressed. Disease transfer and hitchhiking species are also major concerns (McKindsey et al. 2007). Similarly the wider ecological effects including the novel habitat emergence from exotics or/and aquaculture escapees are studied (Forrest et al. 2009, Lallias et al. 2015).

Europe currently produces approximately 800,000 tonnes of molluscs. This represents $24 \%$ of the overall EU aquaculture production in mass and approximately $50 \%$ in value (Robert et al. 2013). Annual French production accounts for approximately 160,000 tonnes of bivalves with nearly $50 \%$ of the oyster Crassostrea gigas $(79,000)$ and $48 \%$ of mussels (Mytilus edulis and M. galloprovincialis: 77,000 issued from aquaculture) (Agreste 2014). French oyster production has undergone a drastic decline from 108,000 to 80,000 tonnes over the last ten years due to epizootic events (Samain et al. 2007, Nicolas et al. 2007, Agreste 2014, Pernet et al. 2012, 2016). Despite a $5.4 \%$ increase in mussel production along the French Atlantic coastline since 2001, a particular decrease in Mytilus edulis growth performance has been recorded, especially in 2011 (Rodriguez 2013).

During the winter of 2014, unprecedented mass mortalities of Mytilus edulis occurred in a coastal inlet of the mid-French Atlantic Ocean, the Breton Sound. 9,000 metric tonnes of mussels were lost and mortality rates up to $100 \%$ were recorded at some farming areas. This 
mortality event had important economic consequences since this area shelters important blue mussel farming sites with an overall marketed production representing 8,705 tonnes or $12 \%$ of the total French volume (Agreste 2014). This rearing area also plays a critical role for spat collecting operations at a national level and sustains the spat supply to several other French rearing areas.

This 2014 event was particularly surprising since Mytilus edulis was so far considered as a resilient cultivated species and sustainable aquaculture production. Contrarily to the Pacific oyster Crassostrea gigas culture, very few mass Mytilus edulis mortalities occurred along the French Atlantic coast and specifically over the Breton Sound until this winter of 2014. For example, the parasite $M$. intestinalis induced mortality rates up to $100 \%$ locally at off-bottom culture sites in 1960 and 1961 (Brienne 1964). Mussel production declines have been related to abnormal hydroclimatic conditions, such as in the spring of 1989. Abundant rainfall and sudden salinity variations with values below 13 characterized this spring, leading to reduced growth rates rather than mussel mortality (Dardignac et al. 1990). Similarly, strong summer sunshine radiation associated with dry winds, particularly during emersion periods, induced reduced mussel spat survival during heat waves in 1989, 1990 and 1991 (Dardignac and Prou 1995). Massive mussel declumping from off-bottom culture sites due to a weakened byssus by high seawater temperatures (above $25^{\circ} \mathrm{C}$ ) were also observed during the heat wave in the summer of 2003 (Robert and Le Moine 2003). Eventually, in 2011 during the third hottest spring since 1976, low mussel production characterized the entire French Atlantic coast without a significant mortality rate (Rodriguez 2013).

At the global scale, few mass mortality events were reported in farmed mussels too (Eggermont et al. 2014). Munford et al. (1981) attributed a Mytilus edulis mass mortality event in Italy to a trematode infection. In the spring of 2001, 10,000 metric tonnes of mussels were lost in the Oosterschelde estuary (Netherlands) due to a combination of high river discharge, strong northerly winds and the transport and sedimentation of a Phaeocystis bloom (Peperzak and Poelman 2008). Earlier, Dutch mussel volumes were significantly impacted by the high abundance of the parasite copepod Mytilicola intestinalis during the autumn and spring of 1949 and 1950, respectively (Meyer and Mann 1951).

Because of its singularity, the blue mussel mass mortality event observed in winter 2014 in the Breton Sound led to preliminary consulting studies (Béchemin et al. 2014, Garcia et al. 2015, François 2015). These latter suggested two potential causes of mortality (i) the existence of particular environmental conditions in winter and (ii) the apparition of a pathogenic organism that both could weaken mussels' populations and lead to observed 
mortalities. A pathogenic Vibrio splendidus bacterial strain was specifically detected in 80 to $100 \%$ of the analysed mussels in the sound at that period (Garcia et al. 2015, François 2015). We proposed in this work to study more in details the potential environmental drivers associated to the specific spatio-temporal patterns of mussel mortalities. Firstly, through an original coupling approach, we described and characterized the sub-surface seawater masses (from January to April 2014) using in situ measurements from Ifremer monitoring networks and satellite-derived chlorophyll $a$ and non-algal suspended particulate matter. We statistically compared the specific environmental conditions from the winter of 2014 to larger temporal scales using a multi-decade time-series of in situ and satellite data available since 1998. Secondly, through 3D hydrodynamic model simulations, we discussed the potential links between field observed patterns of mussel mortality rates and the existence of a pathogenic organism (Vibrio splendidus in that case) that could have spread progressively from one culture site to others. In conclusion, a plausible scenario endorsed by the different observations and in situ-satellite-modelling approach was developed.

\section{Materials and methods}

\subsection{Study site}

The Breton Sound represents a coastal area inlet of the Poitou-Charentes region located on the French Atlantic coast between the Ile de Ré and the continent (Fig. 1). The sound is characterized by a mean surface and volume of $425 \mathrm{~km}^{2}$ and 4,920 million $\mathrm{m}^{3}$, respectively (Stanisière et al. 2006, Soletchnik et al. 2015). Nearly $20 \%$ of this 13.8 meter-deep coastal bay correspond to intertidal areas. It allows the settlement of both off-bottom ("bouchots") and long-line ("filières") mussel culture farms $\left(4.5 \mathrm{~km}^{2}\right.$ in total) where blue mussels have been farmed since the $13^{\text {th }}$ and $20^{\text {th }}$ centuries respectively. Off-bottom farms ("bouchots") consist in rows of wooden poles where mussels are grown directly on it (Fig. 1); they're deployed perpendicularly to the shore and stuck in the sandy/muddy bottom within the gently sloping intertidal strip. Long-line farms ("filières") consist in long-line systems with dropper sleeves or mussel socks (Garen et al. 2004). The Breton Sound is under the influence of a main watershed of $4,074 \mathrm{~km}^{2}$. The Lay and the Sèvre Niortaise Rivers, with mean discharges of 14 and $44.4 \mathrm{~m}^{3} \mathrm{~s}^{-1}$, respectively, represent the main freshwater inputs to the sound (Soletchnik et al. 2015) (Fig. 1). It also receives significant external inputs from the Loire and Gironde Estuaries at the north and south, respectively, depending on hydrodynamic and meteorological forcing (Soletchnik et al. 2015). Semi-diurnal tides from the Atlantic Ocean 
enter the sound by openings between 2 and $10 \mathrm{~km}$ long (Fig. 1). Along with winds and river discharges, this determines the general circulation and renewal time of seawater masses. The renewal times for the Breton Sound are generally above 85 days compared to solely 2 to 18 days for the Marennes-Oléron Bay further south (Stanisière et al. 2006, Ascione Kenov et al. 2015).

\subsection{Sampled seawater stations and in situ data}

Two main stations were monitored during the present study to permit spatial and temporal in situ data comparisons in the sound: Station A, associated to a long-line mussel culture site in the centre of the sound where the mortalities first appeared, and Station $\mathrm{C}$ up north of the sound associated to off-bottom farms reached by mortalities later (Fig. 1 and Table 1). Phytoplankton communities and related water column variables (sub-surface $\sim 0.50 \mathrm{~m}$ seawater temperature, salinity, chlorophyll $a$ concentration and turbidity, Table 1) were evaluated via the French Phytoplankton Monitoring Network REPHY (Ifremer) at least twice a month (Belin and Raffin 1990).

High frequency measurements of temperature and salinity were also done at Station A through the regional monitoring network SAPERCHAIS. The in situ sub-surface seawater ( $0.50 \mathrm{~m}$ ) values were recorded every 10 minutes from January until April 2014 with a STPS sensor (NKE Instrumentation) (Table 1 and Fig. 2).

\subsection{Satellite-derived products and associated stations}

Satellite-derived products (sub-surface seawater temperature, turbidity, chlorophyll $a$ and sea surface irradiance) were estimated at four stations inside the Breton Sound, Stations A and B described above and Stations $\mathrm{C}$ and $\mathrm{D}$ at the east of the sound associated to off-bottom culture sites reached by mortalities too (Figs. 1, 2 and 3 and Tables 1 and 2).

\subsubsection{Ocean colour data}

Chlorophyll $a$ was obtained from the Ifremer OC5 algorithm tuned for the coastal seawaters investigated in this study (Gohin et al. 2002, Gohin 2011).

The semi-analytical model was used to retrieve non-algal suspended particulate matter (SPM) from satellite reflectance as described in Gohin et al. (2005) and Gohin (2011). The phytoplankton effect on the absorption and backscattering properties was approached through a preliminary estimate of the chlorophyll concentration by the OC5 algorithm (Gohin et al. 2002). The non-algal SPM was estimated from the radiance at $\lambda=555 \mathrm{~nm}$ or $\lambda=670 \mathrm{~nm}$ 
depending on the SPM level retrieved $\left(4 \mathrm{gm}^{-3}\right)$. Turbidity was derived from chlorophyll $a$ and non-algal SPM using the formulation provided in Gohin (2011). SeaWiFS, MERIS (MEGS8.1) and MODIS reflectance are the most up-to-date products available from the space agencies in 2012. Since 2012, the MODIS products are the current L2 products available through subscription to the OceanColor NASA/GSFC Centre. Daily-interpolated images of chlorophyll $a$ and turbidity were used (Saulquin et al. 2011) (Fig. 2 and 3 and Tables 1 and 2).

\subsubsection{The Sea Surface Solar irradiance (SSI)}

The SSI is the solar irradiance (in Watt $\mathrm{m}^{-2}$ ) that reaches the Earth surface in the $\lambda=0.3-4 \mu$ $\mathrm{m}$ band. The processing chain for deriving SSI from the data of MSG (METEOSAT Second Generation) satellites is fully described in the SSI Product Manual and available on the OSI SAF web server (EUMETSAT 2013). The validation of the SSI products provided by the OSI SAF is described in Le Borgne et al. (2006) (Fig. 2).

\subsection{The Hydrodynamic model MARS3D-PC}

The tri-dimensional MARS3D modelling approach was used to better understand seawater hydrodynamics associated to the mussel mortality event of the winter of 2014. The MARS3D model solves the primitive equations that are well suited to describe ocean dynamics at the required spatial and temporal scales (Lazure and Dumas 2008). It was developed by Ifremer and implemented and validated on the Breton Sound (MARS3D-PC) for the present study following Stanisière et al. (2006) and Bernard (2011). The model was discretized into $500 \mathrm{~m}$ by $500 \mathrm{~m}$ horizontal cells (Fig. 4). The vertical discretization was performed in a sigma coordinates framework, which provided 40 vertical layers that were tightened close to the bottom and to the surface to catch the boundary layer dynamics. The MARS3D-PC model relied on 1030 by 461 meshes and extended from the Vilaine Bay in the north to the Spanish coast in the south. It then took into account all of the potential runoff (daily mean discharges from Hydro Bank for Vilaine, Loire, Lay, Sèvre Niortaise, Charente, Seudre, Gironde, Leyre and Adour, Fig. 4). The air-sea exchanges were computed based on the bulk formulae and meteorological analysed fields (ARPEGE and AROME MeteoFrance systems). Meteorological outputs along the open boundaries came out as a wider model (MANGA, Lazure et al. 2009) and tidal forcing was estimated from the SHOM CST France database. Initial and boundary conditions came out in the MANGA 2500 Ifremer model covering the run simulations from January $1^{\text {st }}$ (to allow a numerical stabilization of the model) to April $1^{\text {st }}$, 2014, under realistic conditions. 
With regards to hydrodynamic simulations, one tracer (named $a$ ) located in the Breton Sound, was released at Station A on March $9^{\text {th }}, 2014$, the day before the first blue mussel mortality was reported at this long-line culture site (Béchemin et al. 2014). The simulated tracer was used to assess the possible relationship between hydrodynamics and the spatio-temporal patterns of mussel mortalities observed that winter of 2014. It behaved as a conservative, dissolved tracer and was injected at a rate of $1000 \mathrm{~kg} \mathrm{~m}^{-3} \mathrm{~s}^{-1}$ over eight days. All of these parameterizations were chosen to better assess seawater dynamic effects on mussel mortality trends in March of 2014. We also assumed here the possible relationships with a pathogen organism dispersion (i.e. Vibrio splendidus strain). Biological aspects of the pathogen were not considered on purpose but were discussed later in the study. To quantify the mortality trends and the hydrodynamic connectivity among the mussel sites of the sound, daily mean concentrations $\left(\mathrm{kg} \mathrm{m}^{-3}\right)$ of the simulated tracer $a$ were computed until the end of March, 2014, at the four stations associated with mussel culture mortalities, i.e., Stations A (long-line systems), B, C and D (off-bottom systems) (Figs. 1 and 5).

\subsection{Mortality rate estimates and pathogenic organism monitoring}

The Competent Authority (DDTM) estimated the blue mussel mortality rates four times through March 2014, i.e., days 10, 17, 27 and 28 at the different mussel culture sites of the sound at each time, i.e., Stations A, B, C, and D (Fig. 1 and the result section). One to three samplings of approximately $1.5 \mathrm{~kg}$ each were weighed. A second weighing was conducted after the removal of live mussels and a mean loss rate was estimated for each sampled station (Fig. 1).

\subsection{Statistical tools}

Data post-processing (graphs and statistics) was performed using the GraphPad Prism version 6.00 software (La Jolla California USA, www.graphpad.com) and Statgraphics Centurion XVI. The Shapiro-Wilk test was used to test the normality of the data (p-value below 0.05). Non-parametric tests using Mann-Whitney and Kruskall-Wallis (p-value below 0.05) were performed to detect significant differences in the seawater masses' parameters among the stations, methodologies and winters (Table 2). To investigate the temporal variability in the Breton Sound, 17 winters' records from 1998 to 2014 at Station A were analysed and used to perform a principal component analysis (Fig. 3). QGIS and MATLAB software were used to post-process netcdf files from the MARS3D outputs (Figs. 4 and 5). 


\section{Results}

\subsection{Blue mussel mortality estimates}

In early March of 2014, highly significant Mytilus edulis mortality rates first appeared in the centre of the sound at Station A (88 to $100 \%$ - 10/03/14, Fig. 1). Then, in mid-March and in the same sector, mortalities spread up north at Station B where high rates were also reported (90 to $100 \%$ - 17/03/14) (Fig. 1). Eventually in late March of 2014, the mortalities shifted to the eastern part of the sound and reached Stations C and D showing lower but still important rates (50 to $80 \%-27 / 03 / 14$ and $34 \%-28 / 03 / 14$, respectively). One could notice that mortalities already started in mid-March at Station C though in lower rates (16 \% - 17/03/14). By month's end, only basic or routine mortalities below $10 \%$ were observed in the Antioche Sound in the south.

\subsection{Winter 2014 environmental variations and spatio-interannual comparisons}

The surface seawater physico-chemical parameters obtained from in situ measurements and satellite data at Station A showed important environmental variations (Fig. 2 and Table 2). The temperature values ranged between $8.3^{\circ} \mathrm{C}(19 / 01 / 14$ at $04: 00)$ and $13.3{ }^{\circ} \mathrm{C}(13 / 03 / 14$ at 14:10) and averaged $10.2 \pm 0.8^{\circ} \mathrm{C}$ between January and March 2014 (Fig. 2A and Table 2). In January, the seawater temperature exceeded $10{ }^{\circ} \mathrm{C}$ for twenty days. The high frequency in situ measurements revealed large salinity variations ranging from a maximum of $32.6(04 / 02 / 14$, 20:30) to a minimum of $16.0(07 / 03 / 14,16: 50)$ (average of $29.3 \pm 2.3)$. Particularly, several successive and short (15 min.) salinity drops were observed. For example, these drops occurred on February $17^{\text {th }}$ at $23: 40$ and the February $23^{\text {rd }}$ at $02: 30$ with values of 16.5 and 20.4, respectively (Fig. 2A). Large variations in turbidity levels were also noticed (range: 1-72 NTU, Table 2) with numerous peaks at the end of January and February 2014 (values above 70 and 55 NTU, respectively, Fig. 2B). Two phytoplankton blooms occurred at Station A on February $6^{\text {th }}$ and March $22^{\text {nd }}$ with chlorophyll $a$ concentrations of 4.5 and $11 \mu \mathrm{g} \mathrm{L}^{-1}$, respectively (Fig. 2C). These blooms were mainly due to the diatom Skeletonema costatum development with increasing sea surface irradiance at the end of February (values above 200 w $\mathrm{m}^{-2}$, Fig. 2C and Table 2).

With regard to the spatial variations, the east was generally more turbid than the west of the sound in the winter of 2014 (Kruskall-Wallis test, $\mathrm{p}<0.05$; Table 2). The turbidity values were significantly higher at Station C than values measured at Station A $(66.5 \pm 65.3$ and $17.3 \pm$ 13.4 NTU, respectively; Table 2). Similar chlorophyll $a$ concentrations were observed with 
mean values of $2.5 \pm 2.0$ and $2.8 \pm 1.9 \mu \mathrm{g} \mathrm{L}^{-1}$ reported at Stations A and C, respectively. Regarding temporal variations observed at Station A, the ACP analysis showed that subsurface seawaters of the winter of 2014 were not significantly different from other winters between 1998 and 2014. The winter of 2014 corresponded to the second least salty, warmest, most chlorophyll $a$-enriched and most turbid winter (Fig. 3). The winter of 2001 appeared more singular with particularly large freshwater inputs.

\subsection{Hydrodynamic simulations in the northern sound during March 2014}

Hydrodynamic simulations showed that the tracer $a$ released at Station A on March $9^{\text {th }}, 2014$, was rapidly transported and diluted by the seawater masses during the first few days (Fig. 4). March $12^{\text {th }}, 2014$, the tracer $a$ moved to the eastern part of the sound and reached the offbottom sites at Station C in low concentrations (0.08-0.12 $\mathrm{kg} \mathrm{m}^{-3}$, Fig. 4). Then from March $14^{\text {th }}$ to $16^{\text {th }}, 2014$, the tracer reached the off-bottom sites up north at Station B in higher concentrations (close to $0.80 \mathrm{~kg} \mathrm{~m}^{-3}$ ) whereas concentrations remained low and close to 0.08 $\mathrm{kg} \mathrm{m}^{-3}$ at Station C (Fig. 4). At that time (17/03/2014), the estimated mortality rates reached 90 to $100 \%$ at Station B and around $16 \%$ at Station C (Fig. 1 and 4). After March $18^{\text {th }}$, the tracer moved outside of the northern sound to reach the north coastline. Meanwhile, it progressed to the eastern part before entirely overlaying the off-bottom sites at Stations $\mathrm{C}$ and D around March $20^{\text {th }}-22^{\text {nd }}$ in still low concentrations $\left(0.08-0.23 \mathrm{~kg} \mathrm{~m}^{-3}\right.$, Fig. 4). March $22^{\text {nd }}$, 2014, the tracer moved out of the sound to the south in low concentrations by the La Rochelle Strait (Fig. 4). Mussel mortality rates at Stations C and D were reported later than the tracer arrival in this area.

The diffusion model simulation outputs at each station in the sound associated with seawater height variations is presented in Figure 5. March $12-13^{\text {th }}$ the highest concentrations were logically predicted at Station A (the closest site from the tracer release point) with $1.40 \mathrm{~kg} \mathrm{~m}^{-}$ 3. From March $12^{\text {th }}$ to $18^{\text {th }}$, the tracer $a$ slightly appeared at Station $\mathrm{C}$ with very low concentrations (0.1-0.2 $\mathrm{kg} \mathrm{m}^{-3}$, Fig. 5). Then, from March $16^{\text {th }}$ to the end of March, predicted concentrations increased to a higher extend at Station B $\left(0.65 \mathrm{~kg} \mathrm{~m}^{-3}\right.$, Fig. 5). March $18^{\text {th }}$, the estimated concentrations slightly increased at Station C and D (0.3-0.4 and 0.1-0.2 $\mathrm{kg} \mathrm{m}^{-3}$, respectively, Fig. 5) though they were estimated to be three times lower compared to Station B. In late March 2014, still important but lower mortality rates were reported in the eastern off-bottom sites of the sound (50-80\% and $34 \%$ at Stations C and D respectively, Fig. 1 and $5)$. 


\section{Discussion}

\subsection{Validity of the modelling approach methodology}

Base on the timing of the observations, we used a modelling approach to study potential seawater hydrodynamic effects on spatio-temporal mussel mortality patterns during March of 2014. We focused on purpose on potential hydrodynamic drivers rather than integrating pathogens' biology elements to the present approach. Indeed, little is known about marine bacterial pathogens. The Vibrio splendidus group in particular Vibrio splendidus-related strains and their interactions with farmed aquatic animals are still poorly studied (Le Roux and Austin, 2006; see cited references). However, we assumed that this pathogen was potentially dispersed by hydrodynamics. Indeed, characteristics of the aquaculture environment such as hydrodynamic connectivity, mixing and/or confinement of waters are often addressed in bivalve disease epidemic studies (Salama and Murray 2011, Leguerrier et al. 2006, Bacher et al. 2016 and others). Béchemin et al. (2014) carried out an ex-situ experiment placing together in the same bath moribund and healthy mussels collected in winter of 2014 in the Breton Sound. This experiment led to the death of the healthy mussels showing that a pathogen transmission by water was possible. We recognize that, bivalve age, origin, farming practices and life history traits are other important factors potentially implied in transfer of diseases related to mortalities (Pernet et al. 2012). The Breton Sound is a significant rearing area that sustains spat supplies to several other French rearing areas. Despite the regulatory framework at the international and national levels, mussel transfers from/in the Breton Sound could also be a potential vector of pathogen transmission. Eventually, Vibrio splendidus was shown to accumulate notably in the gonad of adult oysters. Sugumar et al. (1998) suggested that brood stock could be the source and a transmission way (vertical transmission).

In our hydrodynamic simulation, the tracer $a$ was then used as a point source of potential pathogen to reproduce further dispersion within the sound, taking into account water advection and dilution/mixing. The hydrodynamic model provides the footprint of the tracer plumes that may describe the worst situation; indeed, a large injection rate of tracer was used since the quantity of pathogens that could be released into the seawater column was unknown. We decided to choose an injection rate of $1000 \mathrm{~kg} \mathrm{~m}^{-3} \mathrm{~s}^{-1}$ over a time period of eight days (from the day before the first mortalities were reported). This injection rate allowed us to mimic as best as possible the seawater hydrodynamic movements at that period, knowing the number of days (i.e. 4-6 days) between the beginning and the end of mortalities at one site and 
the take-over to another site. It was also chosen to take into account pathogen biological aspects using this time period of tracer injection based on $\mathrm{T}_{90}$ (i.e. the time needed to decrease $90 \%$ of pathogen quantity in the field) values found in the literature. For example, Pernet et al. (2012) in the Thau lagoon estimated a value of five days to model ostreid herpesvirus 1 (OsHV-1) transmission into Crassostrea gigas oysters. Salama et al. (2011) showed that $\mathrm{T}_{90}$ values ranged from 8 to 65 days were appropriated to explain fish virus transmission among farms.

\subsection{Blue mussel mortality observations and the winter of 2014 environmental characterization}

The spatio-temporal evolution of farmed mussel mortalities in the Breton Sound in March 2014 was based on in situ estimates and monitoring. The latter could have solely been done during four days in March 2014 and then could lead to some uncertainties. Lupo and Prou (2016) showed that adapted monitoring programs of shellfish mortality were necessary to improve early detection and investigation of outbreaks of emerging infectious diseases using the 2014 event as a case study. However, a spatialisation of the mortality intensity was observed; a progressive spatio-temporal dispersion of the mortality rates occurred, first at the long-line culture site (Station A), before reaching the off-bottom sites in the north (Station B) and to the east of the sound (Stations C and D). Such high mussel mortality rates were never specifically reported in the Breton Sound. Between 7,000 and 9,000 metric tonnes of mussels were lost that winter with a volume far above losses previously noticed (Brienne 1964, Dardignac et al. 1990, Robert and Le Moine 2003, Rodriguez 2013, see introduction section). Robert et al. (2015) at the end of Spring 2014 confirmed the cumulative mortality rate estimated through March field samplings. Actually, they reported mortality rates reaching 100 $\%$ in the Breton Sound (in particular, 100 and $96 \%$ at Stations A and C, respectively). In contrast, the mortality rates did not exceed $10 \%$ outside of the sound (in the southern sound) or in the north over the French coast.

We found that winter environmental 2014 characteristics were influenced by the positive North Atlantic Oscillation (NAO+) index as described by Cassou (2004). The sum of Autumn 2013 and Winter 2014 had the third highest NAO index since 1865 (Hurrell 2014). This might be responsible for the significant climate variability observed along the French Atlantic coastline with regard to wind regimes, temperatures, rainfalls and pressure fields. The satellite data analysis over the 1998-2014 period showed a singular anomaly of suspended particulate matter (close to $10 \mathrm{mg} \mathrm{L}^{-1}$ ) in March 2014 along the whole Atlantic coast (Gohin et al. 2015). 
High temperature values, turbidity peaks and salinity drops were consequently measured along the French coast and recovered in the seawater masses of the sound in March (Fig. 2 and 3). Interestingly, the winter interannual comparisons since 1998 at Station A showed these particular environmental variations characterized 2014 but also other winters whereas no comparable mussel mortality rates were reported (Fig. 3 and the results section). However, mortalities were observed nearby under similar conditions for the Pacific oyster Crassostrea gigas, for example, in the Marennes-Oléron Bay in 1976-77, 1988 and 1993 (Héral et al. 1978, Bodoy et al. 1990, Lodato 1997), in the Arcachon Bay in the 1980's (Maurer et al. 1986) and in western Brittany and Normandy in 1994-95 and 2001 (Goulletquer et al. 1998, Fleury et al. 2003, Costil et al. 2005). These oyster mortalities were generally correlated with high winter temperatures and rainfall under positive NAO+ regimes without any mussel mortalities. Then, those particular environmental variations likely affected the sensitivity of the blue mussel populations in winter 2014 in the sound but could not alone explain the observed mussel mass mortality event.

\subsection{Potential environmental influence on mussel mortalities and culture site specificities}

Under these particular environmental variations, we reviewed the different factors that could lead to mussel weakness and mortalities. In the winter of 2014, it is unlikely that mussel mortalities resulted from declumping from their supports from byssus weakening. Such mortalities occurred in summer 2003 for instance and were characterized by a seawater temperature above $25^{\circ} \mathrm{C}$ (Robert and Le Moine 2003). Conversely, it has been shown that byssus production increased in the winter with enhanced hydrodynamic conditions (Young 1985). With regard to the salinity decline, Dardignac et al. (1990) showed experimentally that periods of several days with seawater salinity values below 15 were necessary to induce mussel mortalities. Then, the combined effects of salinity drops, turbidity peaks and seawater height amplitude variations during that particular winter probably weakened the blue mussel populations. In this case, more energy could have been allocated to byssus production, particle sorting and food ingestion (Bennet-Clark 1976, Barillé et al. 1997). Robert et al. (2015) measured during the winter of 2014 the lowest flesh indices since 2001 at the different mussel culture sites in the sound (Walne and Mann quality indexes of 131 and 78 at Stations $\mathrm{A}$ and $\mathrm{C}$, respectively). This then supported the negative effect of high turbidity values on blue mussels.

On the other hand, the negative effects of particular winter environmental conditions as those observed in 2014, on mollusc reproduction have previously been studied (see Costil et al. 
2005, Samain et al. 2007 for the Pacific oyster Crassostrea gigas). In the Magdalen Islands (southern Gulf of St. Lawrence), Myrand et al. (2000) suggested that blue mussels at long-line culture sites paid a high reproductive cost. It was particularly true as soon as the major spawning occurred concomitantly with stressful environmental conditions such as high seawater temperatures (from 20 to $13^{\circ} \mathrm{C}$ ). In the Breton Sound the winter mussel spawning event that can occur with lower seawater temperatures above $9-10^{\circ} \mathrm{C}$ was probably a key factor as well (Lubet 1959, Boromthanarat 1986). The 2014 annual survey of larvae abundance conducted in the sound observed early mussel spawning in February 2014 (CREAA 2014). The twenty days in January with temperature above $10^{\circ} \mathrm{C}$ at the long-line site likely led to an early mussel spawning and then weakening at this specific location (always immersed).

\subsection{Potential pathogen apparition/dispersion and mussel culture site hydrodynamic connectivity}

Preliminary consulting studies on the 2014 mortality event suggested the existence of particular winter environmental conditions and the apparition of a pathogenic organism (Vibrio splendidus) that both could weaken mussels' populations and lead to observed mortalities. Vibrio species has long been considered as an environmental organism without pathogenicity. They are common in seawater (Thompson et al. 2005) and different related strains have been associated to deaths in gorgonians, shrimps, fish and mainly molluscs such as Crassostrea gigas (see references cited in Le Roux and Austin 2006, Saulnier et al. 2011). However, Vibrio splendidus was never directly associated to blue mussel Mytilus edulis mortalities. During the Breton Sound's winter outbreak of 2014, the bacteria belonging to the clade Vibrio splendidus were isolated on moribund mussels, and some isolates used in pathological trials specifically induced mortality in live mussels. Between March and April 2014, a pathogenic Vibrio splendidus bacterial strain was detected in 80 to $100 \%$ of the analysed mussels in the sound (Béchemin et al. 2014, Garcia et al. 2015, François 2015). This is the first time Vibrio splendidus clade isolates were directly associated with severe mussel mortalities in this geographical area. In the winter 2014 context of particularly high winter temperatures, mussel metabolism (ingestion and reproduction) was likely enhanced as a result of maturation and early spawning leading to an overall physiological weakness. Lambert et al. (2007) and Nicolas et al. (2007) showed that the Pacific oyster Crassostrea gigas reproduction period was at a greater risk due to decreasing immune defences. Meanwhile, those specific environmental conditions could favour the apparition of this Vibrio splendidus 
bacterial strain that was inactive at lower temperature, eventually inducing mussel mortalities such as those observed in the sound.

In this work, we tried to understand if the Vibrio splendidus clade, once appeared through the seawater column at the long-line site, could have spread toward other mussel culture sites (off-bottom sites) and led to the observed mortality patterns. Based on the timing of the observation, we ran a hydrodynamic simulation using a conservative tracer to explore the connectivity of the sound, which could explain the timing of the spread of the disease (see references in 4.1.). Although not a definitive demonstration, the modelling simulations corroborated the progressive dispersion of mortality rates over time and space observed in March 2014 in the sound. It is interesting to notice that the tracer displacement simulations slightly differed from the observed mortality patterns. Indeed, from Station A (long-line site initially reached by mortalities), the simulated tracer reached Station C (off-bottom sites to the east of the sound) faster than Station B (off-bottom sites up north) whereas significant mortalities were reported at Station B before C. Leguerrier et al. (2006) and Bacher et al. (2016) developed coastal connectivity concepts in bays and estuaries on the eastern coast of Canada also interested in shellfish aquaculture, i.e. residence times, transfer time and rate. The idea in our case study would be that from Station A and under the influence of seawater hydrodynamics at that period, the low pathogen quantities reaching the off-bottom sites to the east of the sound (Station C) would probably be not enough to trigger a mortality event. Meanwhile, the main pathway for the pathogen would be to move around the sound especially toward the off-bottom sites up north of the sound (Station B) with high quantities. This time, Vibrio splendidus quantities would probably be enough to be able to induce mortalities. Applying coastal connectivity concepts from Leguerrier et al. (2006) and Bacher et al. (2016), it would mean that Stations A and C would be connected with a short transfer time but a low transfer rate. To the contrary, Stations A and B would be connected with a somewhat longer transfer time but a much higher transfer rate. As discussed before (see 4.1. section), physical separation and hydrodynamic connectivity between cultivated and/or wild stocks are generally key factors to consider when developing a disease management plan to further limit disease expansion (Viljugrein et al. 2009, Salama and Murray 2011, Bacher et al. 2016). Work is still on progress regarding these hydrodynamic-pathological linked aspects of the winter 2014 mortality event. Very recently, a studied carried out by Benabdelmouna and Ledu (2016) reported heavy genomic abnormalities (GA) associated with blue mussel mortality outbreaks observed in March of 2014 in the sound. They particularly showed that mussel cultivated stocks with high GA\% values presented high mortality levels. To the contrary 
mussel stocks with low GA\% values and no genomic abnormalities presented low mortality levels. Interestingly, these latter stocks were either isolated or from the southern sound where no mortality occurred. The authors advanced a possible hydrodynamic transport of a causative pathogen agent of mortality transmissible between individuals. They also highlighted an unexpected and unusual fragility of blue mussel populations that winter in the Breton Sound.

\section{Conclusion}

This case study based upon measured data and field observations, represents a likely scenario that involves the combined effects of different factors leading to the severe mussel mortality event of the winter of 2014 in the Breton Sound (Fig. 6). First, particular meteorological conditions (NAO+ regime) characterized by several stormy and rainy events occurred over the period along the entire French Atlantic coastline. High temperatures, turbidity peaks and salinity drops were observed, particularly at the long-line site where mussel mortalities first appeared (“environment”, Fig. 6). Those conditions likely influenced blue mussel sensitivity at this specific culture location, where mussels were always immersed and might have already been weakened by an early spawning event in winter of 2014 ("host", Fig. 6). This particular overall situation potentially facilitated the apparition of a pathogenic strain of Vibrio splendidus bacteria (Béchemin et al. 2014), acting as a "point source" at the long-line site where high densities of blue mussels were farmed. Moreover, the strong coastal hydrodynamic connectivity allowed mussel mortality vector diffusion from this site to others ("pathogen", Fig. 6). The 2014 environmental conditions that allowed the pathogen to appear are complex and still unknown. In marine systems, environment-host-pathogen interactions drive disease outbreaks. Any balance change of these components can shift the system toward higher disease prevalence (Burge et al. 2014). In a lesser extent, this outbreak was also observed in 2015 and 2016 in the same area and up north over the French Coast. This demonstrates the need to better understand the complex interactions among environment-hostpathogen over coastal aquaculture sites. Under major climate change those interactions can alter the likelihood of disease outbreaks (Snieszko 1974, Burge et al. 2014).

\section{Acknowledgements}

We are very grateful to all of our colleagues from the LERPC who participated in the field sampling and lab analysis. We would like to thank DDTM 17 and 85 for the mortality rate estimates and also CRC 17 and 85 who provided valuable observations on mussel mortality 
trends over the winter period 2014. The present work benefited from the DGAL (agreement DGAL N 14/1211521) and DPMA (14/1211522) financial support.

\section{References}

Agreste (2014) Recensement de la conchyliculture 2012, Ministère de l'agriculture, de l'agroalimentaire et de la forêt, Agreste Primeur, 1-6

Kenov Ascione I, Muttin F, Campbell R, Fernandes R, Campuzano FJ, Machado F, Franz G, Neves R (2015) Seawater fluxes and renewal rates at Pertuis d'Antioche/Marennes-Oléron Bay, France. Est. Coast. Shelf Sci., http://dx.doi.org/10.1016/j.ecss.2015.05.031

Bacher C, Filgueira R, Guyondet T (2016) Probabilistic approach of water residence time and connectivity using Markov Chains with application to tidal embayments. J. Mar. Sys.153, 2541. http://doi.org/10.1016/j.jmarsys.2015.09.002

Barillé L, Prou J, Héral M and Razet D (1997) Effects of high natural seston concentrations on the feeding, selection, and absorption of the oyster Crassostrea gigas. J. Exp. Mar. Biol. Eco. 212: 149-172.

Béchemin C, Soletchnik P, Polsenaere P, Le Moine O, Pernet F, Protat M, Fuhrmann M, Quéré C, Goulitquer S, Corporeau C, Renault T, Lapègue S, Travers A, Morga B, Garriques M, Garcia C, Haffner P, Dubreuil C, Faury N, Baillon L, Baud JP (2014) Surmortalités de la moule bleue Mytilus edulis dans les Pertuis Charentais (mars 2014), 1-46. http://archimer.ifremer.fr/doc/00229/34022/

Belin C and Raffin B (1990) Réseau de suivi du phytoplancton (REPHY): Inventaire cartographique des points de prélèvements, 1-82. http://archimer.ifremer.fr/doc/00174/28523/

Benabdelmouna A, Ledu C (2016) The mass mortality of blue mussels (Mytilus spp) from the Atlantic coast of France is associated with heavy genomic abnormalities as evidenced by flow cytometry. J. Inv. Patho. 138: 30-38. http://doi.org/10.1016/j.jip.2016.06.001

Bennet-Clark HC (1976) Marine mussels: their ecology and physiology. International Biological Programme 10. Edited by B. L. Bayne, Cambridge University Press, 1-506. Experimental Physiology, 61 doi: 10.1113/expphysiol.1976.sp002367

Bernard I (2011) Écologie de la reproduction de l'huître creuse, Crassostrea gigas, sur les côtes atlantiques françaises. PhD Thesis, La Rochelle, 1-198. http://archimer.ifremer.fr/doc/00040/15155/

Black KDE (2001) Environmental impacts of aquaculture. CRC Press LLC, Boca Raton, 1214

Bodoy A, Garnier J, Razet D, Geairon P (1990) Mass mortalities of oysters (Crassostrea gigas) during spring 1988 in the bay of Marennes-Oleron related to environmental conditions, Cons. Int. Exp. Mer, C.M. 90/K 11, 1988, 1-23 
Boromthanarat S (1986) Les bouchots à Mytilus edulis dans l'écosystème estuarien du bassin de Marennes-Oléron (france). Aspects biologique et énergétique, $\mathrm{PhD}$ thesis Université AixMarseille II, 1-142

Bouwman L, Beusen A, Glibert PM, Overbeek C, Pawlowski M, Herrera J, Mulsow S, Yu RC, Zhou MJ (2013) Mariculture: significant and expanding cause of coastal nutrient enrichment. Env. Res. Lett. 8. doi:10.1088/1748-9326/8/4/044026

Brienne H (1964) Observations sur l'infestation des moules du pertuis breton par Mytilicola intestinalis STEUER. Revue des Travaux de l'Institut des Pêches Maritimes, 28(3): 205-230

Burge CA, Eakin CM, Friedman, CS, Froelich B, Hershberger PK, Hofmann EE, Petes LE, Prager KC, Weil E, Willis B, Ford SE, Harvell CD (2014) Climate change influences on marine infectious diseases: implications for management and society. An. Rev. Mar. Sci., 6: 249-277

Cassou C (2004) Du changement climatique aux régimes de temps: l'oscillation nordatlantique. La Météorologie 45: 21-32

Costil K, Royer J, Ropert M, Soletchnik P, Mathieu M (2005) Spatio-temporal variations in biological performances and summer mortality of the Pacific oyster Crassostrea gigas in Normandy (France). Helgoland Mar. Res. 59: 286-300

CREAA (2014) Suivi de la Reproduction et du Captage de la moule Mytilus edulis en Charente maritime en 2014. (01/07/2015). http://creaa.pagespersoorange.fr/doc/20_fiche_moule.pdf

Dardignac MJ, Bodoy A, Garnier J, Heurtebise S, Legrand J (1990) Etude de la mortalité des moules dans le Pertuis Breton en 1989. http://archimer.ifremer.fr/doc/00048/15902/

Dardignac MJ and Prou J (1995) A propos des problèmes de captage de naissain de moules (Mytilus edulis L.) dans le Pertuis Breton de 1989 à 1991: Observations préliminaires. Haliotis 24: 13-31

Davenport J, Black K, Burnell G, Cross T, Culloty S, Ekarante S, Furness B, Mulcahy M, Thetmeyer H (2003) Aquaculture: the ecological issues. Blackwell Publishing. Oxford

Eggermont M, Tamanji A, Nevejan N, Bossier P, Sorgeloos P, Defoirt T (2014) Stimulation of heterotrophic bacteria associated with wild-caught blue mussel (M. edulis) adults results in mass mortality. Aquacult. 431: 136-138

EUMETSAT (2013) Geostationary Radiative Flux Product User Manual, version 1.3, April 2013, www.osi-saf.org/index.php

FAO (2013) FishStatJ-Software for Fishery Statistical Time Series (Rome: Fisheries and Aquaculture Information and Statistics Service, Food and Agriculture Organization of the United Nations) www.fao.org/fishery/statistics/software/fishstatj/ en (release data March 2013) 
Fleury PG, Cornette F, Claude S, Palvadeau H, Robert S, D'Amico F, Le Gall P, Vercelli C, Pien S (2003) REseau MOllusques des Rendements Aquacoles huitre creuse (REMORA); résultats des stations nationales; Année 2001, 1-48. http://archimer.ifremer.fr/doc/00000/2438/

Forrest BM, Keeley NB, Hopkins GA, Webb SC, Clement DM (2009) Bivalve aquaculture in estuaries: review and synthesis of oyster cultivation effects. Aquacult. 298(1-2): 1-15 doi:10.1016/j.aquaculture.2009.09.032

François C (2015) Bilan 2014 du réseau national de surveillance de la santé des mollusques marins (REPAMO). 1-44 http://archimer.ifremer.fr/doc/00256/36691/

Garcia C, Lupo C, Travers MA, Arzul I, Dubreuil C, Chollet B, Baillon L, Serpin D, Bazet M, Tourbiez D, Haffner P, Morga B, François C, Tchaleu-Danic G, Faury N, Segarra A, Moreau P, Lapegue S, Renault T (2015). Laboratoire National de Référence pour les maladies des mollusques marins. Faits marquants 2014 et perspectives. Journées de restitutions auprès des partenaires institutionnelles: DPMA and DGAL, 20 mai 2015, Nantes, France.

Garen P, Robert S, Bougrier S (2004) Comparison of growth of mussel, Mytilus edulis, on longline, pole and bottom culture sites in the Pertuis Breton, France. Aquacult. 232: 511-524

Gohin F, Druon JN, Lampert L (2002) A five channel chlorophyll concentration algorithm applied to SeaWiFS data processed by Seadas in coastal seawaters, Int. J. Rem. Sens. 23: 1639-1661

Gohin F, Loyer S, Lunven M, Labry C, Froidefond JM, Delmas D, Huret M, Herbland A (2005) Satellite-derived parameters for biological modelling in coastal seawaters: Illustration over the eastern continental shelf of the bay of Biscay. Rem. Sens. Env. 95: 29-46

Gohin, F (2011) Annual cycles of chlorophyll-a, non-algal suspended particulate matter, and turbidity observed from space and in-situ in coastal seawaters. Ocean Sci. 7: 705-732

Gohin F, Bryere P, Griffiths J (2015) The exceptional surface turbidity of the North-West European shelf seas during the stormy 2013-2014 winter: consequences for the initiation of the phytoplankton blooms? J. Mar. Sys. http://dx.doi.org/10.1016/j.jmarsys.2015.02.001

Goulletquer P, Soletchnik P, Le Moine O, Razet D, Geairon P, Faury N (1998) Summer mortality of the Pacific cupped oyster Crassostrea gigas in the Bay of Marennes-Oléron (France). Conseil International pour l'Exploration de la mer CIEM. http://archimer.ifremer.fr/doc/00000/3093/

Héral M, Berthomé JP, Razet D, Garnier J (1978) Hydrobiological study of the MarennesOleron basin. An example: the drought during summer 1976. Rev. Trav. Inst. Peches Marit. Nantes 42: 269-290

Holmer M, Black K, Duarte CM, Marbà N, Karakassis I (2008) Aquaculture in the ecosystem. Springer-Verlag, Berlin, 1:319

Hurrell J, National Center for Atmospheric Research Staff (Eds) (2014) "The Climate Data Guide: Hurrell North Atlantic Oscillation (NAO) Index (station-based)." Retrieved from 
https://climatedataguide.ucar.edu/climate-data/hurrell-north-atlantic-oscillation-nao-indexstation-based.

Lallias D, Boudry P, Batista F, Beaumont A, King JW, Turner JR, Lapègue S (2015) Invasion genetics of the Pacific oyster Crassostrea gigas in the British Isles inferred from microsatellite and mitochondrial markers. Biol. Inv. 17(9): 2581-2595

Lambert C, Moal J, Pouvreau S (2007) Les risques associés à la physiologie de l'huitre en période de reproduction. In Samain J.F., McCombie H., 2007. Mortalité de l'huître creuse Crassostrea gigas. Défi Morest. Samain J F, McCombie H (eds) Ed Ifremer 51-94

Lazure P, Dumas F (2008) An external-internal mode coupling for a 3D hydrodynamical model for applications at regional scale (MARS). Advances in Seawater Resources 31: 233250. doi:10.1016/j.advwatres.2007.06.010

Lazure P, Garnier V, Dumas F, Herry C, Chifflet M (2009) Development of a hydrodynamic model of the Bay of Biscay. Validation of hydrology. Cont. Shelf Res. 29(8): 985-997

Le Borgne P, Legendre G, and Marsouin A (2006) Validation of the OSI SAF radiative fluxes. Proceedings of the 2006 EUMETSAT Meteorological Satellite Conference, Helsinki, Finland, 12-16 June 2006.

http://www.eumetsat.int/website/home/News/ConferencesandEvents/DAT_2043223.html

Leguerrier D, Bacher C, Benoît E, Niquil N (2006) A probabilistic approach of flow-balanced network based on Markov chains, Ecol. Model. 193(3-4): 295-314. http://dx.doi.org/10.1016/j.ecolmodel.2005.08.036.

Lodato MI (1997) Spring mortality of Crassostrea gigas in the oyster reefs at Perquis and Ronce (France, Bay of de Marennes-Oleron): Study of oyster rearing methodologies and biological and spatial characteristics. PhD Thesis of the Ecole Natl. Vétérinaire, Nantes (France), 1-127

Lubet P (1959) Recherche sur le cycle sexuel et l'émission de gamète chez les mytilidés et les pectinidés. Rev. Trav. Inst. Pêches marit. 23:1-547

Mattsson J, Lindén O (1983) Benthic macrofauna succession under mussels, Mytilus edulis L. (Bivalvia), cultured on hanging long-lines. Sarsia 68: 97-102

Maurer D, Comps M, His E (1986) Caractéristiques des mortalités printanières de l'huître Crassostrea gigas dans le Bassin d'Arcachon. Haliotis 15: 309-317

McKindsey CW, Landry T, O'Beirn FX, Davies IM (2007) Bivalve aquaculture and exotic species: a review of ecological considerations and management issues. J. Shellfish Res. 26(2): 281-294. doi:10.2983/0730-8000(2007)26[281:BAAESA]2.0.CO;2

Mckindsey CW, Archambault P, Callier M, Olivier F (2011) Influence of suspended and offbottom mussel culture on the sea bottom and benthic habitats: a review. Canadian J. Zool. 89(7): 622-646. Publisher's official version: http://dx.doi.org/10.1139/Z11-037 
MEA (2005) Millennium Ecosystem Assessment, Ecosystems and Human Well-being: Synthesis. Island Press, Washington, DC. 1-137

Meyer PF and Mann H (1951) Recherches allemandes relatives au "Mytilicola", copépode parasite de la moule, existant dans les watten allemandes 1950/51. . Rev. Trav. Inst. Pêches marit. 17: 63-75. http://archimer.ifremer.fr/doc/00000/6753/

Munford JG, DaRos L, Strada R (1981) A study on the mass mortality of mussels in the Laguna Veneta. J. World Aquacult. Soc. 12(2): 186-199

Myrand B, Guderley H, Himmelman J.H. (2000) Reproduction and summer mortality of blue mussels Mytilus edulis in the Magdalen Islands, southern Gulf of St. Lawrence. Mar. Ecol. Prog. Ser. 197: 193-207

Nicolas JL, Renault T, Gagnaire B, Garcia C, Garnier M, Gay M, Labreuche Y, Le Roux F, Miossec L, Pépin JF, Saulnier D (2007). Risques associés aux pathogènes. In Samain J.F, McCombie H, 2007. Mortalité de l'huître creuse Crassostrea gigas. Défi Morest. Monographie, 6: 229-269

Peperzak and Poelman (2008) Mass mussel mortality in The Netherlands after a bloom of Phaeocystis globosa (prymnesiophyceae). J. Sea Res. 60(3): 220-222

Pernet F, Lagarde F, Cesmat L, Jeannée N, Barret J, Le Gall P, Quere C, Fiandrino A, Miguet M, Boulet H, Keck N, Roque D'Orbcastel E (2012) Facteurs explicatifs de la dynamique spatio-temporelle des mortalités d'huîtres creuses Crassostrea gigas dans la lagune de Thau, 1-58. http://archimer.ifremer.fr/doc/00092/20355/

Pernet F, Lupo C, Bacher C, Whittington RJ (2016) Infectious diseases in oyster aquaculture require a new integrated approach. Phil. Trans. R. Soc. B 371: 20150213. http://dx.doi.org/10.1098/rstb.2015.0213

Richard M, Archambault P, Thouzeau G, McKindsey CW, Desrosiers G (2007) Influence of suspended scallop cages and mussel lines on pelagic and benthic biogeochemical fluxes in Havre-aux-Maisons Lagoon, Îles-de-la-Madeleine (Quebec, Canada). Can. J. Fish Aquat. Sci. 64(11): 1491-1505. doi:10.1139/ F07-116

Robert S, Le Moine O (2003) Expertise des élevages de moules après la canicule estivale: rapport final, 1-41 http://archimer.ifremer.fr/doc/00074/18511/

Robert R, Sanchez JL, Perez-Paralle L, Ponis E, Kamermans P, O'Mahoney M (2013) A glimpse on the mollusc industry in Europe. Aquacult. Eur. 38(1): 5-11

Robert S, Bouget JF, Fleury E, Chauvin J, Gagnery A, Normand J, Blin JL, Cheve J, Dagault F, Gerla D, Lejolivet A, Penot J, Chabirand JM, Genauzeau S, Geairon P, Grizon J, Le Moine O, Schmitt-Gallotti A, Seugnet JL, Soletchnik P (2015) Réseau national d'observation de la moule bleue Mytilus edulis (MYTILOBS, Campagne 2014-2), 1-61. http://archimer.ifremer.fr/doc/00270/38086/

Rodriguez J (2013) Performances d'élevage de la moule bleue (Mytilus edulis) en Manche/Atlantique. Recensement et interprétation. 1: Synthèse et rapport, 1-147 
Ruckelshaus M, Doney SC, Galindo HM, Barry JP, Chan F, et al. (2013) Securing marine ecosystem services in the face of climate change. Mar. Policy. 40: 154-59

Salama NKG, Murray AG (2011) Farm size as a factor in hydrodynamic transmission of pathogens in aquaculture fish production. Aquacult. Env. Interact. 2: 61-74

Samain et al. (2007) Synthèse générale et recommandations pour la gestion et la prévision des mortalités estivales. In Samain J.F., McCombie H, 2007. Mortalité de l'huître creuse Crassostrea gigas. Défi Morest. Monographie. 8: 291-331

Saulnier D, Pépin JF, Guesdon S, Degrémont L, Faury N, Haffner P, Renault T, Travers A, Tourbiez D, Geairon P, Le Moine O, Seugnet J-L, Soletchnik P (2011) Mortalités massives de l'huître creuse - Rapport final du programme de recherche sur l'étude de la cinétique de détection d'agents infectieux associés à des épisodes de mortalités de naissains d'huîtres creuses Crassostrea gigas sur un site ostréicole de Marennes-Oléron, 1-52 (CIDAGINF 20092010). http://archimer.ifremer.fr/doc/00058/16920/

Saulquin B, Gohin F, Garrello R (2011) Regional objective analysis for merging highresolution meris, modis/aqua, and seawifs chlorophyll-a data from 1998 to 2008 on the european atlantic shelf. Transactions on Geoscience and Remote Sensing. 49: 143-154

Snieszko SF (1974) The effects of environmental stress on outbreaks of infectious diseases of fishes. J. Fish Biol. 6: 197-208

Soletchnik P, Polsenaere P, Le Moine O, Guesdon S, Béchemin C (2015) Relations entre apports terrigènes et conchyliculture dans les Pertuis Charentais, 1-53 http://archimer.ifremer.fr/doc/00248/35964/

Stanisière JY, Dumas F, Plus M, Maurer D, Robert S (2006) Caractérisation des composantes hydrodynamiques d'un système côtier semi-fermé: Le Bassin de Marennes-Oléron, 1-112 http://archimer.ifremer.fr/doc/00000/2353/

Staudinger MD, Grimm NB, Staudt A, Carter SL, Chapin FS III, et al. (2012) Impacts of climate change on biodiversity, ecosystems, and ecosystem services: technical input to the 2013 National Climate Assessment. Coop. Rep. 2013 Natl. Clim. Assess., Washington DC, $1: 296$

Sugumar G, Nakai T, Hirata Y, Matsubara D, Nluroga K (1998) Vibrio SfJ/cndidus biovar II as the causative agent of bacil- lary necrosis of Japanese oyster Crassostrca gigas larvae. Dis. Aquat. Organ. 33: 111-118

Thompson JR, Pacocha S, Pharino C, Klepac-Ceraj V, Hunt DE, Benoit J, Sarma-Rupavtarm R, Distel DL, Polz MF (2005) Genotypic diversity within a natural coastal bacterioplankton population. Science. 307: 1311-1313

Troost K, Gelderman E, Kamermans P, Smaal AC, Wolff WJ (2009) Effects of an increasing filter feeder stock on larval abundance in the Oosterschelde estuary (SW Netherlands). J. Sea Res. 61(3): 153-164. doi:10.1016/j.seares.2008.11.006 
Viljugrein H, Staalstrøm A, Molvær J, Urke HA, Jansen PA (2009) Integration of hydrodynamics into a statistical model on the spread of pancreas disease (PD) in salmon farming. Dis. Aquat. Org. 88: 35-44

Young GA (1985) Byssus-thread formation by the mussel Mytilus edulis: effects of environmental factors. Mar. Ecol. Prog. Ser. 24: 261-271

\section{Figure captions}

Fig. 1. A map of the Breton Sound with studied stations. Station A (-1.3769, 46.2781); Station B (-1.3897, 46.3320); Station C (-1.2339, 46.2731) and Station D (-1.2000, 46.2475). The stations that were studied were chosen precisely at the different mussel culture sites reached by mortalities (long-line: Station A, off-bottom: Stations B, C and D) in the sound and where network-monitoring data were available (see Table 1). Off-bottom sites are intertidal and 3 to 4.5 meters high; mussels are kept under 4 to 6 meters deep. Long-line culture sites are located in areas of 10 to 15 meters deep and are suspended under 1 to 2 meters of water.

Fig. 2. The sub-surface seawater parameters measured at Station A where mortalities first occurred (01/01-31/03/2014). (A) Temperature (T, ${ }^{\circ} \mathrm{C}$ ) and Salinity (S); (B) Turbidity (TU, NTU, log scale); (C) chlorophyll $a$ concentration ( $\left.[\mathrm{Chl} a], \mu \mathrm{g} \mathrm{L}^{-1}\right)$ and Irradiance $\left(\mathrm{I}, \mathrm{W} \mathrm{m}^{-2}\right)$. T and $\mathrm{S}$ were measured every 10 minutes by a STPS probe (NKE) (STPS; the black points correspond to daily averages); T, TU, Chl $a$ and I daily mean values were estimated by satellite image analysis (SAT); T, S, TU, and Chl $a$ were measured by REPHY every 2 weeks (REPHY). The vertical dashed line corresponds to the beginning of the mortality event at Station A (09/03/2014).

Fig. 3. A loading plot of the principal component analysis (PCA) (total explained variance = $85.99 \%)$. It was realized with winters' mean data measured at Station A over 17 winters (1998-2014) and it shows functions of the four measured factors (4 variables) and the correlations between the variables: Turbidity (TUR, NTU; SAT), chlorophyll $a$ concentration (CHL $a, \mu \mathrm{g} \mathrm{L}^{-1}$; SAT), Temperature (TEMP, ${ }^{\circ} \mathrm{C}$; REPHY) and Salinity (SAL; REPHY). The horizontal axis explains $72.29 \%$ of the variability and the vertical axis explains $13.71 \%$.

Fig. 4. The evolution of the daily mean concentration $\left(\mathrm{kg} \mathrm{m}^{-3}\right)$ of the simulated tracer $a$ in the Breton Sound released at Station A on March $9^{\text {th }}, 2014$. Simulations were performed with the MARS3D-PC model (resolution 500 meters; $1030 \times 461$ meshes, top-left corner) using a dissolved and conservative initial bottom flux.

Fig. 5. (A) Mean concentration $\left(\mathrm{kg} \mathrm{m}^{-3}\right)$ evolution of the simulated tracer $a$ in the Breton Sound at Stations A, B, C and D during March of 2014 (Fig. 1). Each curve represents the tracer concentration estimated at each station over time. (B) The seawater height computed at Station A and according to the mean sea level (MARS3D, FES 2004). Time step: two hours.

Fig. 6. Overview scheme: environment/mussel/pathogen interactions in the Breton Sound in winter 2014 (modified from Snieszko 1974). 
Fig. 1.

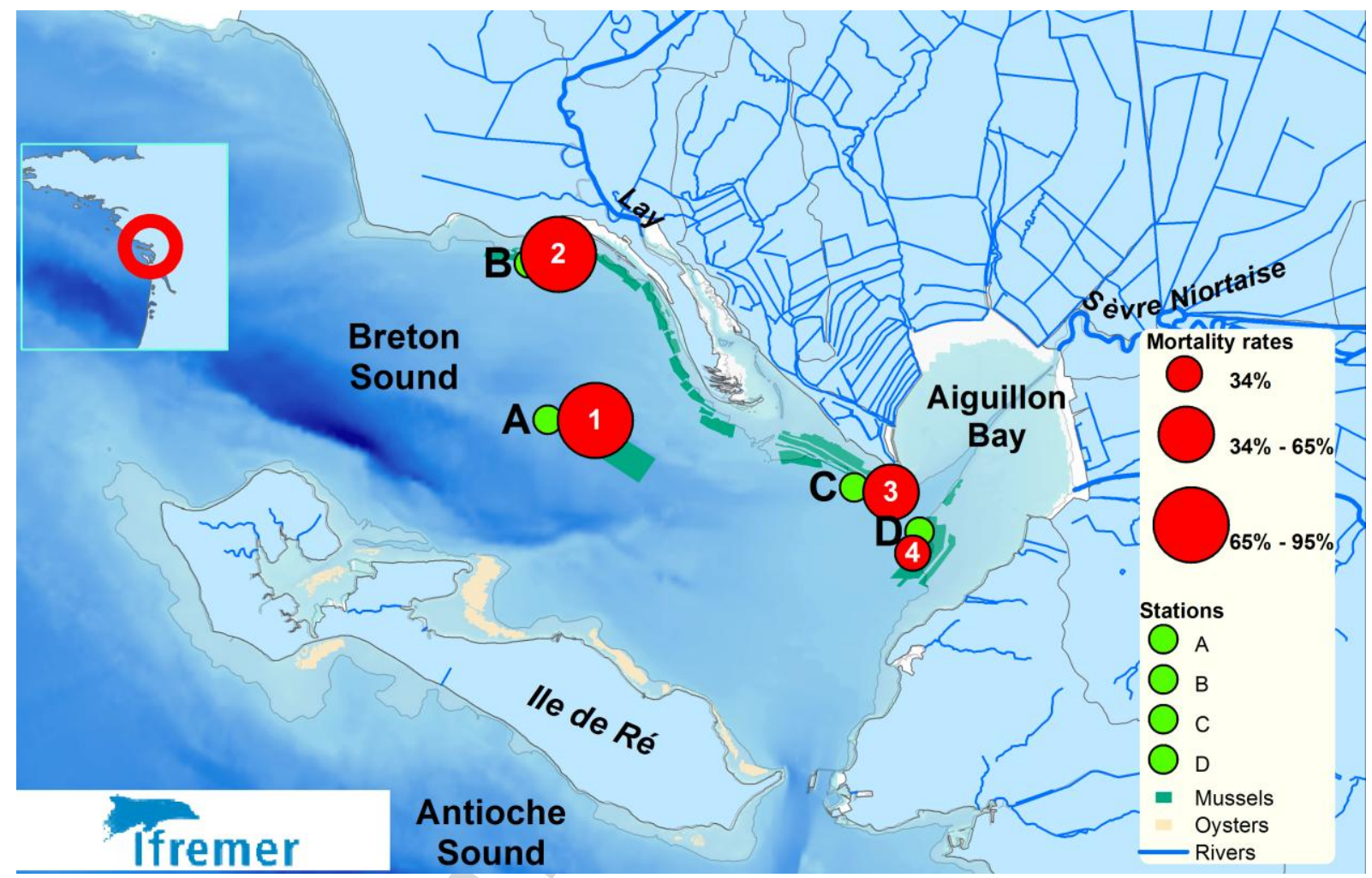


Fig. 2.

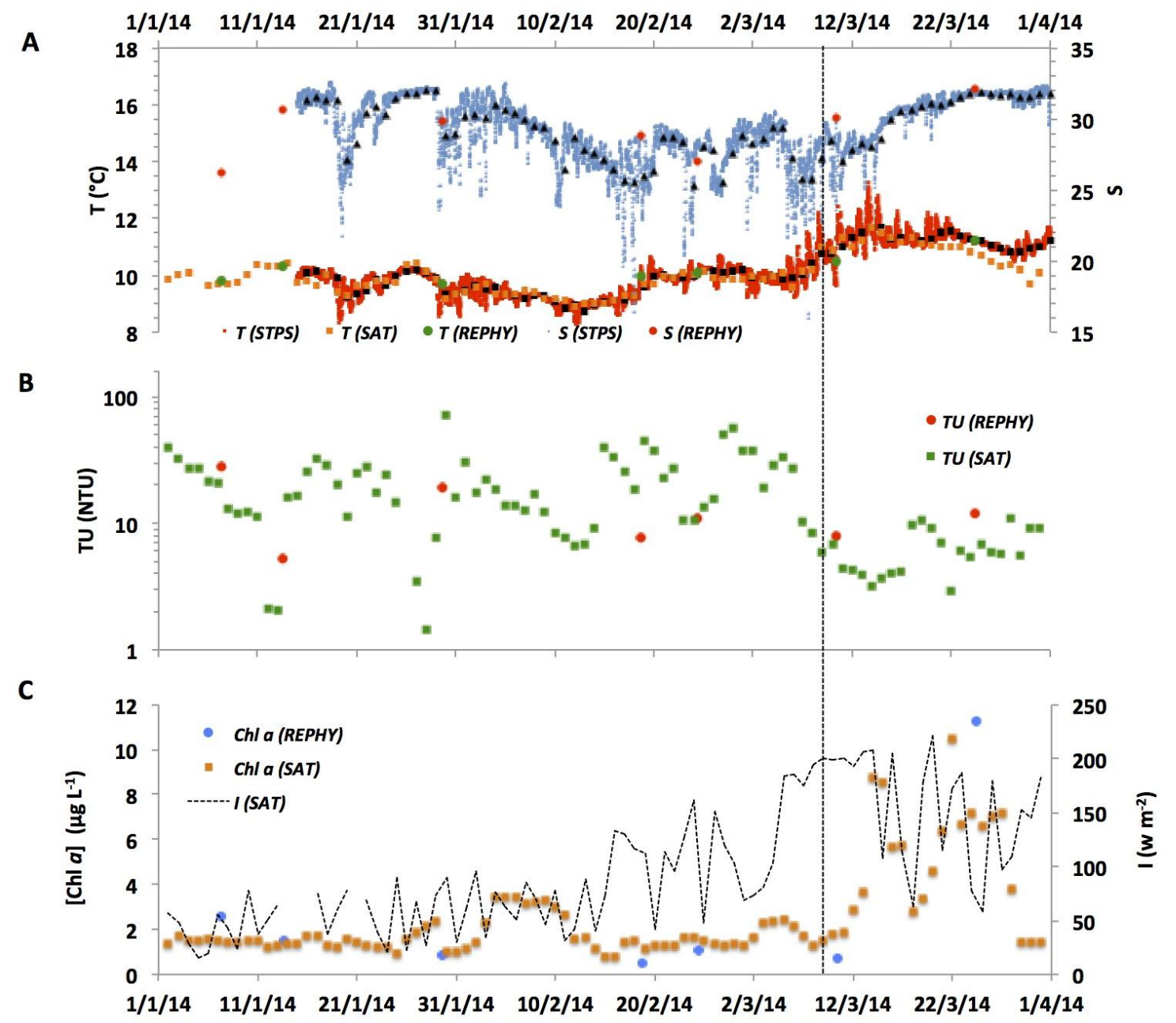


Fig. 3.

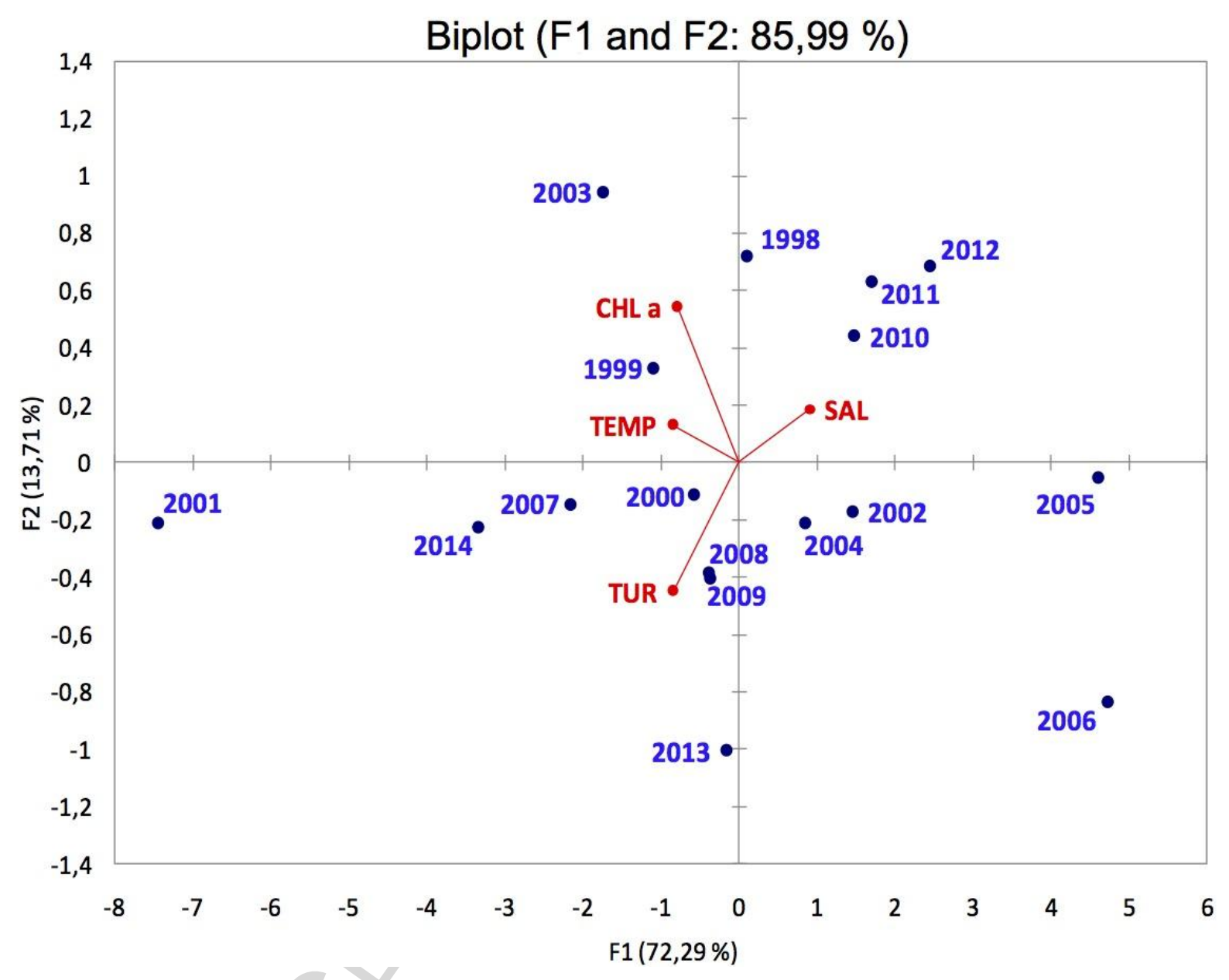



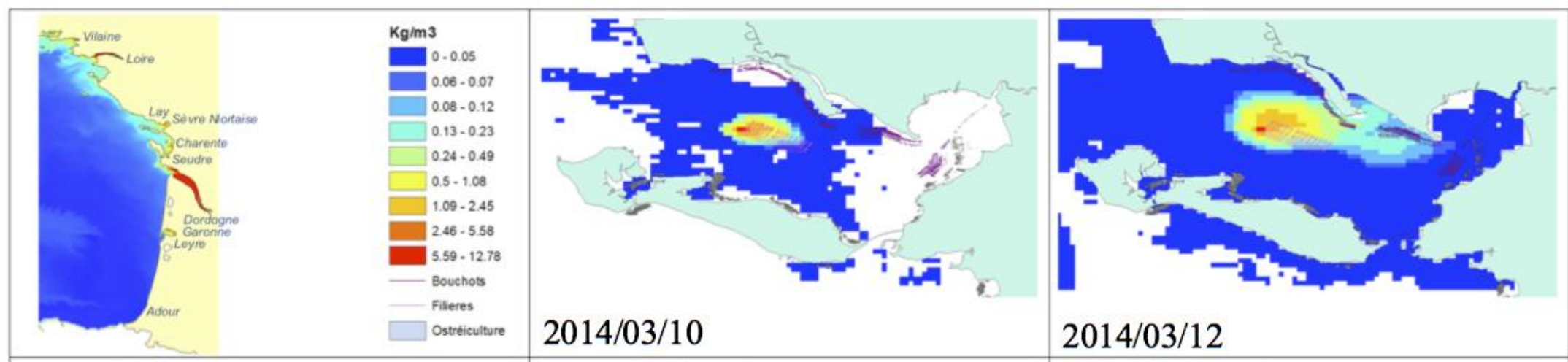

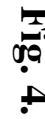

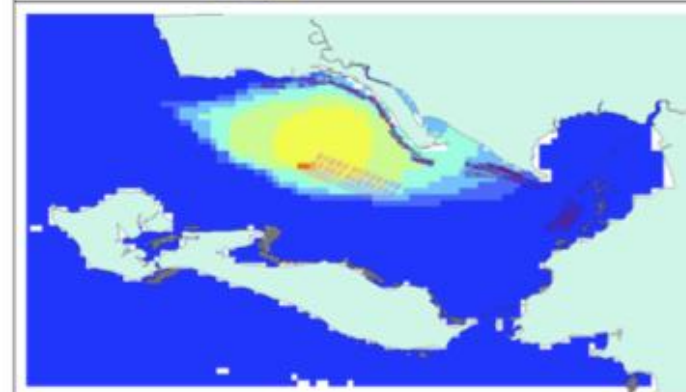

2014/03/14

2014/03/10

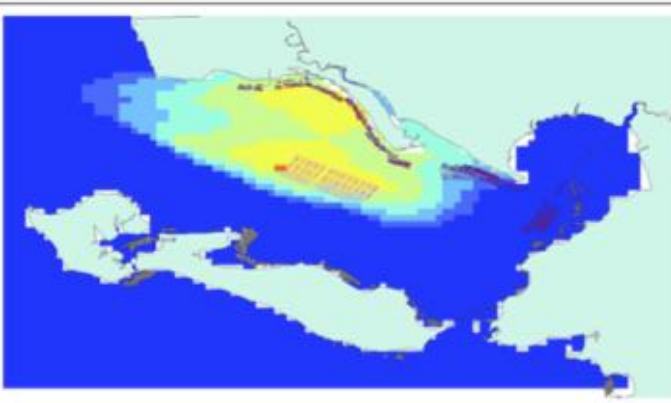

2014/03/16

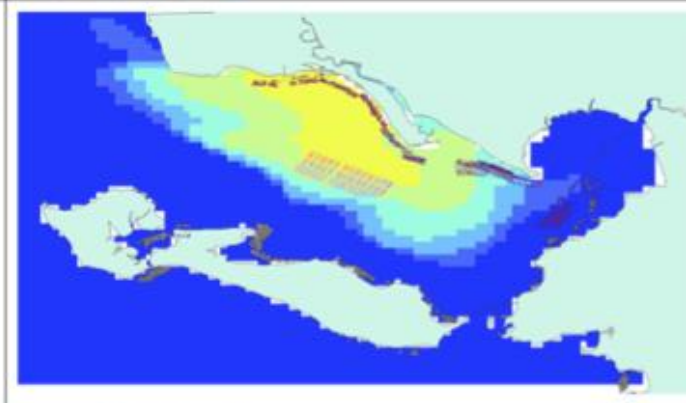

2014/03/18

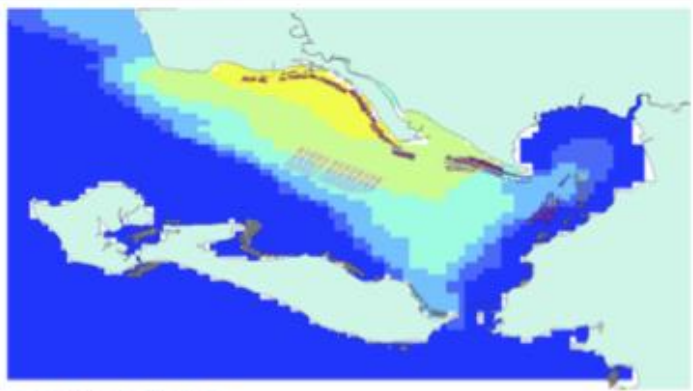

$2014 / 03 / 20$
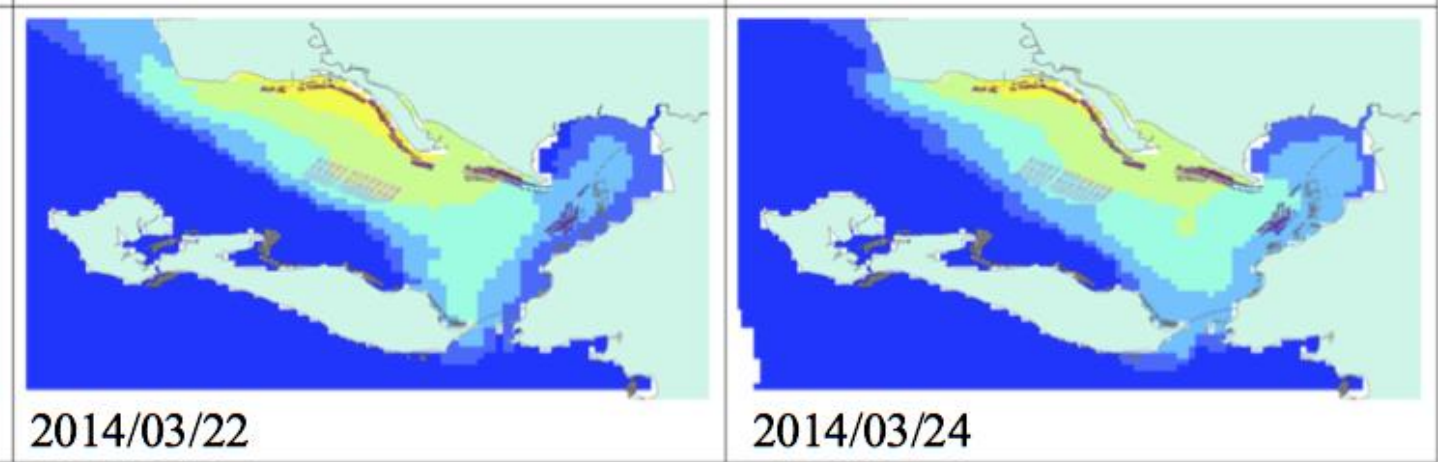
Fig. 5.

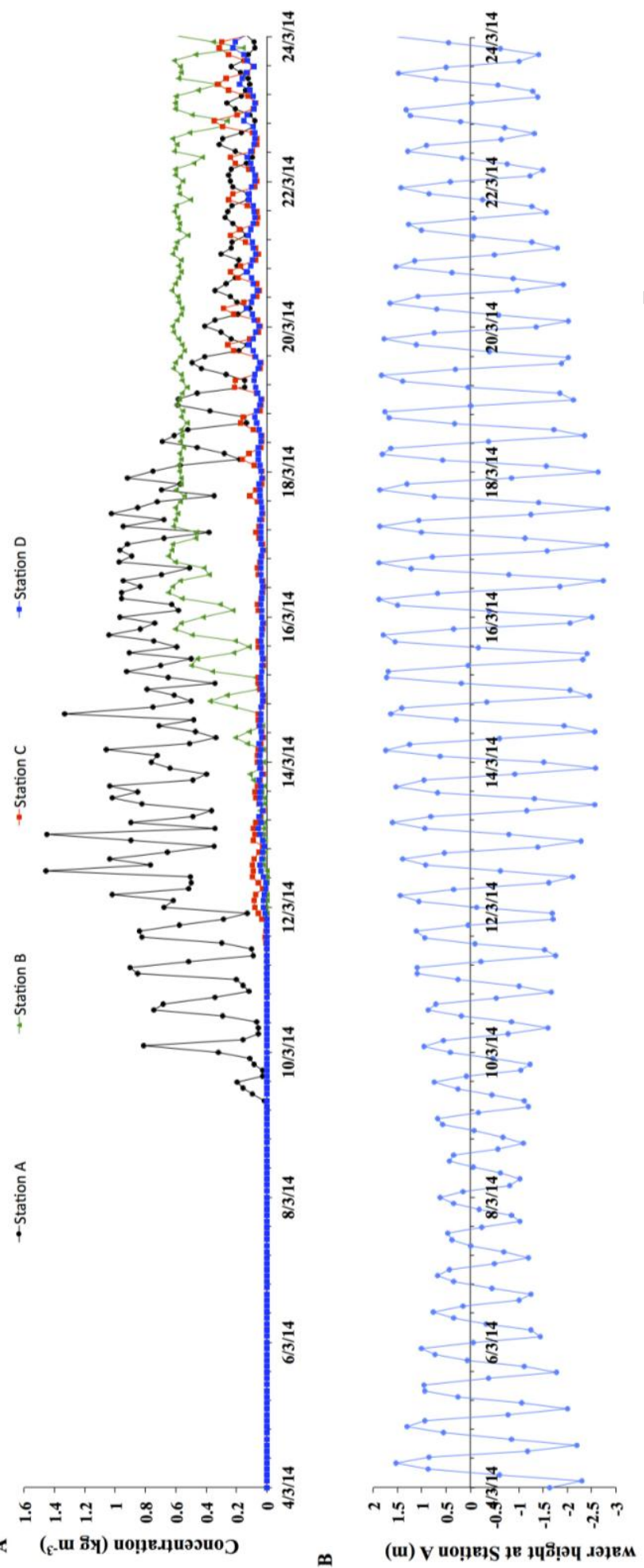


Fig. 6.

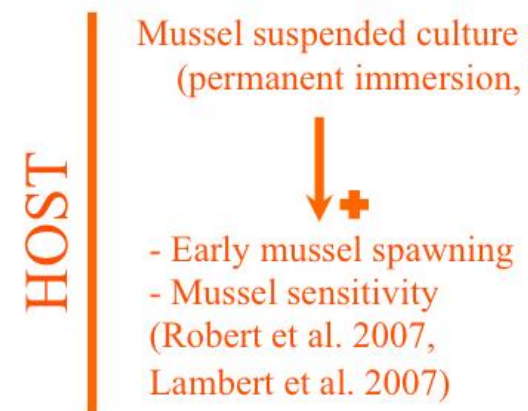

Lambert et al. 2007)
The epidemiological triad

(Snieszko 1974)

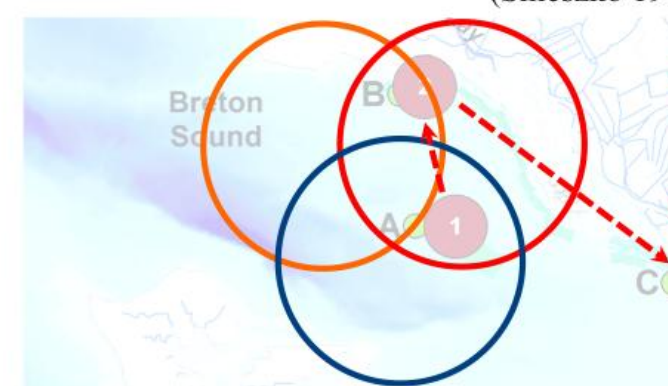

Pathogen organism apparition (hydrodynamic connectivity, ecological window)

(Nicolas et al. 2007, Samain \& McCombie 2007)
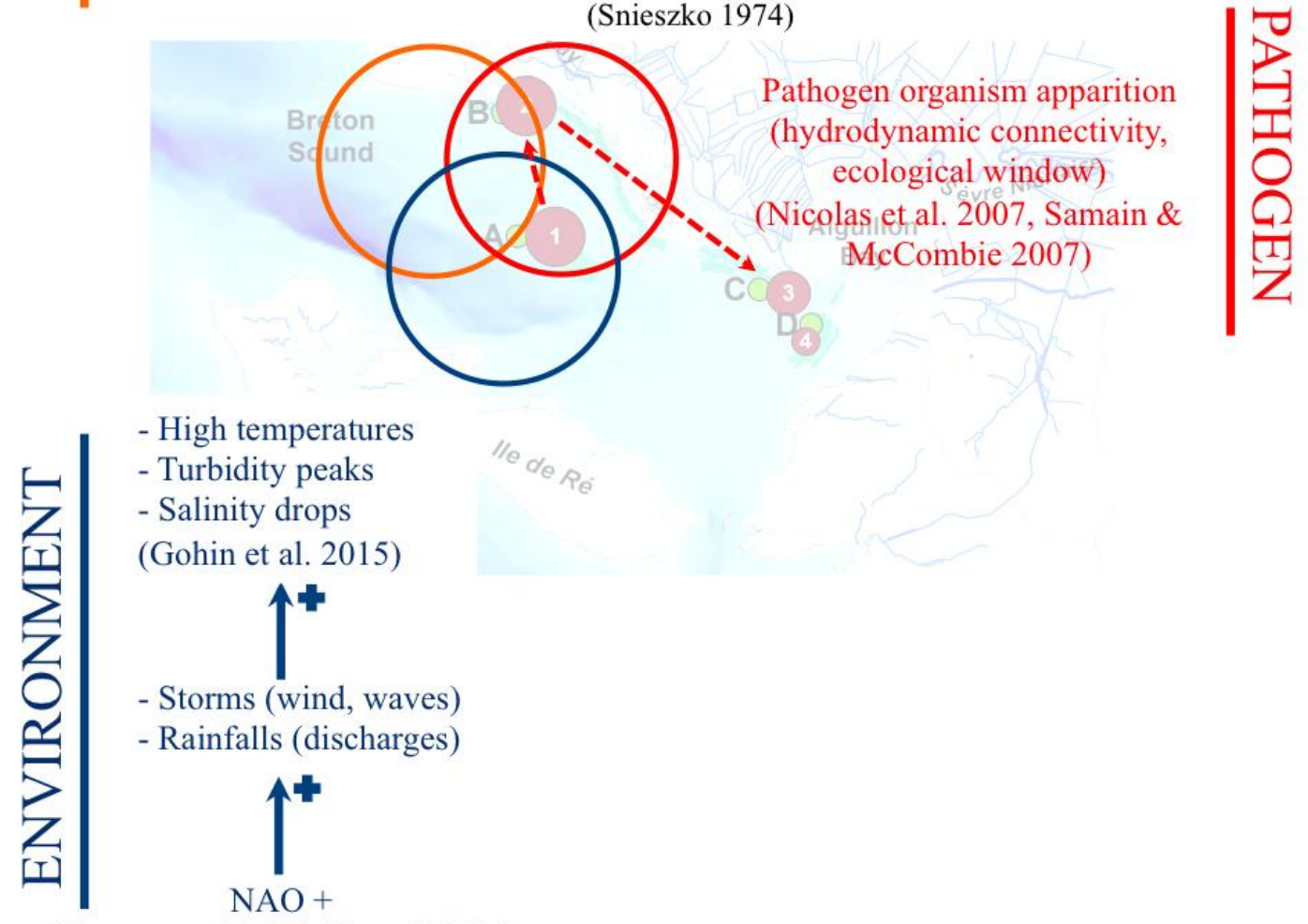

(Cassou et al. 2004, Hurrell 2014) 
Table 1. The environmental parameter database characteristics of the studied stations in the Breton Sound (see Figs. 1 and 2). SAPERCHAIS: regional monitoring network; REPHY: French Phytoplankton Monitoring Network; Satellite: satellite-derived products (temperature, turbidity, chlorophyll $a$ and sea surface irradiance); MARS3D: tri-dimensional hydrodynamic model.

\begin{tabular}{lllcl} 
Stations & Parameters & Time step & Period & Network/Project \\
\hline A, B, C, D & $\begin{array}{l}\text { Blue mussel mortality } \\
\text { rates (\%) }\end{array}$ & $\begin{array}{l}1 \text { to 3 samplings per day } \\
\text { for each station each day }\end{array}$ & $10 / 03 / 14$ & $\begin{array}{l}\text { DDTM17 and } \\
\mathbf{8 5}\end{array}$ \\
& & $17 / 03 / 14$ & \\
& & $27 / 03 / 14$ & \\
& & & \\
& & & \\
& & & \\
\end{tabular}

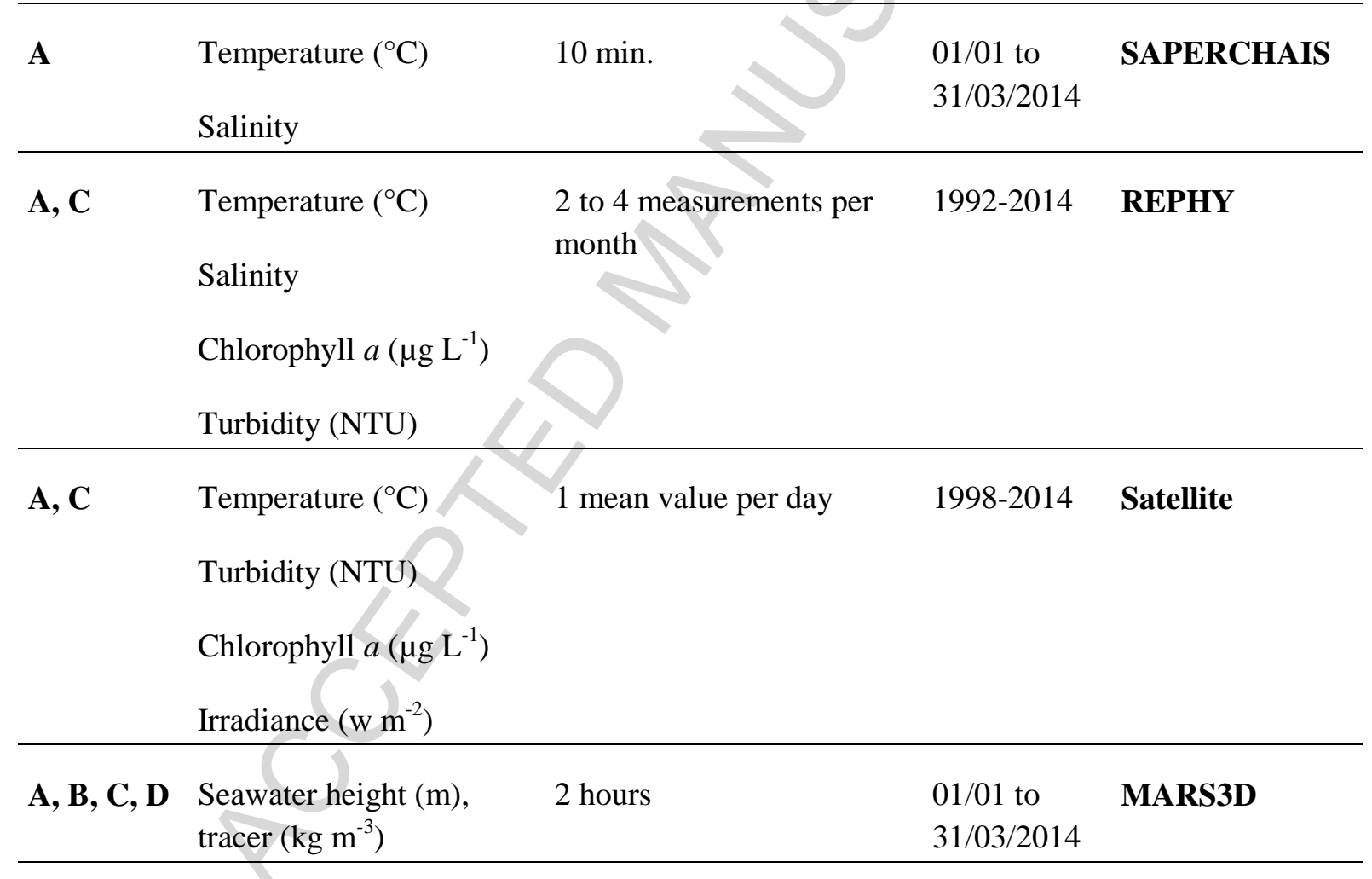


Table 2. The surface seawater parameters measured at Stations A and C from January 1 to March 31, 2014. T: temperature, S: salinity, TU: turbidity, Chl $a$ : chlorophyll $a$ and I: irradiance. Average \pm standard deviation; range (between brackets); n (number of values). See Figure 1. and Table 1 for station information. No significant differences were found between the different sources of data except for turbidity values between REPHY and the satellites (Mann-Whitney and Kruskal Wallis tests, p-value: 0.05). No significant inter-station differences were noticed with REPHY data; the turbidity values estimated from the satellites at Station A were found to be significantly different from Station C (Kruskal Wallis tests, pvalue: 0.05). It is important to notice that each station was affected differently by mussel mortalities (see Fig. 1.).

\begin{tabular}{|c|c|c|c|c|c|}
\hline \multicolumn{2}{|c|}{$\begin{array}{l}\text { Stations } \\
\text { (REPHY, STPS, SAT) }\end{array}$} & \multicolumn{2}{|l|}{$\mathbf{A}$} & \multicolumn{2}{|l|}{ C } \\
\hline \multirow[t]{4}{*}{$\mathbf{T}\left({ }^{\circ} \mathbf{C}\right)$} & STPS min. & $10.2 \pm 0.8$ & $(8.3-13.3) \mathrm{n}=10929$ & & \\
\hline & STPS day & $10.2 \pm 0.8$ & $(8.7-11.7) \mathrm{n}=76$ & & \\
\hline & SAT & $10.0 \pm 0.6$ & $(8.9-11.7) n=88$ & $10.0 \pm 0.8$ & $(8.7-12.1) \mathrm{n}=89$ \\
\hline & REPHY & $10.2 \pm 0.5$ & $(9.7-11.2) \mathrm{n}=7$ & $10.3 \pm 0.7$ & $(9.8-11.4) n=7$ \\
\hline \multirow[t]{4}{*}{$\mathbf{S}$} & STPS min. & $29.3 \pm 2.3$ & $(16.0-32.6) \mathrm{n}=10929$ & & \\
\hline & STPS day & $29.3 \pm 2.0$ & $(25.3-32.0) \mathrm{n}=76$ & & \\
\hline & SAT & & & & \\
\hline & REPHY & 29.3 & $(26.2-32.1) n=7$ & $25.1 \pm 2.7$ & $(20.8-28.5) \mathrm{n}=7$ \\
\hline \multirow[t]{4}{*}{ TU (NTU) } & STPS min. & & & & \\
\hline & STPS day & & & & \\
\hline & SAT & 17. & $(1.4-72.0) n=88$ & $66.5 \pm 65.3$ & $(7.7-358.1) n=87$ \\
\hline & REPHY & $13.0 \pm 8.0$ & $(5.2-28.1) \mathrm{n}=7$ & $19.2 \pm 8.3$ & $(8.9-31.5) \mathrm{n}=7$ \\
\hline \multicolumn{6}{|c|}{ Chl $a\left(\mu \mathrm{g} \mathrm{L}^{-1}\right)$ STPS min. } \\
\hline & SAT & $2.5 \pm 2.0$ & $(0.8-10.5) \mathrm{n}=89$ & $2.8 \pm 1.9$ & $(1.0-10.9) \mathrm{n}=89$ \\
\hline & REPHY & $2.6 \pm 3.8$ & $(0.5-11.2) \mathrm{n}=7$ & $3.9 \pm 5.6$ & $(0.8-16.6) n=7$ \\
\hline \multirow[t]{4}{*}{$\operatorname{SSI}\left(\mathbf{w} \mathbf{~ m}^{-2}\right)$} & STPS min. & & & & \\
\hline & STPS day & & & & \\
\hline & SAT & $96.9 \pm 58.1$ & $(15.2-221.7) n=86$ & $96.4 \pm 57.7$ & $(17.0-223.9) \mathrm{n}=86$ \\
\hline & REPHY & & & & \\
\hline
\end{tabular}

